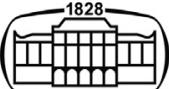

AKADÉMIAI KIADÓ

\title{
The tradition of facet-cut bowls from Pannonia - New fragments from Brigetio
}

\author{
Kata Dévai* [
}

\section{Acta Archaeologica Academiae Scientiarum Hungaricae}

72 (2021) 2, 253-265

DOI:

$10.1556 / 072.2021 .00015$

(c) 2021 The Author(s)

\section{ORIGINAL RESEARCH} PAPER

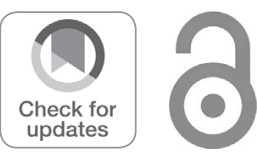

Premium Postdoctoral Program of MTA Eötvös Loránd University, Múzeum Krt. 4/B, H-1088 Budapest, Hungary

Received: June 4, 2021 • Accepted: June 22, 2021

\section{ABSTRACT}

The method of facet-cutting was invented in the $1^{\text {st }}$ century AD. The glass cutters began to create zoned facet-cut decoration to arrange the facets in horizontal zones divided by linear grooves mostly in Isings 96 bowl in the second half of $2^{\text {nd }}$ century and first half of $3^{\text {rd }}$ century AD. A look at the distribution and the major concentrations of sites reveals that they had been manufactured in four main regions: the Rhine region (perhaps at Cologne), Pannonia, Syria (possibly at Dura Europos) and the Pontic, at Tanais. Its popularity is best indicated by the fact that this elegant ornamental technique began to be applied on silverware which clearly imitated the glass bowls, as shown by the adoption of the Isings 96 hemispherical bowl form that was lacking from among silver vessels.

\section{KEYWORDS}

Roman glass vessels, facet-cut decoration, facet-cut bowls, Pannonian glass vessels

Hemispherical bowls with facet-cut ornamentation were used during a brief period in Pannonia. These colourless, good quality vessels have a thick wall of 3-4 mm and are decorated with carefully designed and executed engraved motifs. The vessel body is divided into bands by one or more wheel-cut lines, while the bands are filled with oval or round facets separated by single or double rod-shaped motifs (Fig. 5.1, Fig. 5.3). ${ }^{1}$ One essential precondition to the spread of this decorative mode was the growing popularity of colourless glass for tableware on which this type of ornamentation was truly attractive.

The use of facet-cut motifs arranged into rows can be noted from the 60s and 70s AD in Italy, where it was employed to decorate cups and bowls, which soon became highly popular. Decoration of glassware with engraved lines spread across the entire empire and attained immense popularity on colourless or greenish bowls. ${ }^{2}$ Simple wheel-cut and incised lines could be easily added at the place of production, in the glass workshops. However, it seems more likely that more elaborate designs of engraved lines and facet-cut oval and circular motifs combined with rice-grain facets were made in specialised workshops. ${ }^{3}$ This decoration system corresponds to German Ornamentaler Hochschliff and the English term facet-cut. ${ }^{4}$ An upswing in the use of this decorative technique can be noted in the later second century $\mathrm{AD}$, when it was principally employed on hemispherical bowls, whose ornamentation followed elaborate decorative schemes that covered the entire vessel surface. ${ }^{5}$ Several origins have been proposed for facet-cut motifs, which made their first appearance in the band under the rim of first-century AD terra sigillata vessels. However, on glass vessels, facets were made in a different size and as part of an elaborate decorative system; moreover, glass vessels have no

${ }^{1}$ Barkóczi (1988) Form 25. a-b; Isings (1957) Form 96; Rütti (1991) Form AR 56 and 60.159; Harter (1999) Form A 16; Hoffmann (2002) Form C3.3.1.9; Paolucci (1977) 100, 101; Sakl-Oberthaler and Tarcsay (2001) Taf. 3.23-24; Šaranović-Svetek (1986) Tab. I.4,8.

${ }^{2}$ Fünfschilling (2015) 85-87.

${ }^{3}$ Fünfschilling (2015) 85-87.

${ }^{4}$ Cottam and Price (1998) 115; Fünfschilling (2015) 85-87.

${ }^{5}$ Paolucci (1997) 63 
other motifs aside from the facet-cut ones, while these are often used in combination with other motifs on terra sigillata bowls. Moreover, the vessel forms differ substantially and thus we can only speak of the similarity of the motifs. ${ }^{6}$ It has been convincingly demonstrated that the workshops and glasscutters producing this type of engraved decoration worked closely together with the glassblowers. Bowls and cups decorated in this manner were distributed across entire Western Europe, from Scandinavia to Britain, and from Gaul and Germany to Spain and Italy. Nevertheless, a visible concentration can be noted in the Cologne area. In the east, this glass ware is attested in Pannonia, Syria and Palestine, Egypt and the Pontic. ${ }^{7}$

A look at the distribution and the major concentrations of sites reveals that they had been manufactured in four main regions: the Rhine region (perhaps at Cologne), Pannonia, Syria (possibly at Dura Europos) and the Pontic, at Tanais. ${ }^{8}$ The western part of the Roman Empire is emphasized in production, the existence of workshop in the Dura Europos and Tanais is uncertain. Facet-cut vessels often appears also along the Rhine and in Southern Germany, Bavaria. But there are also rich places in Northern Italy, as Brescia for example and also known in France and Great Britain, but not in big quantities. Its popularity is best indicated by the fact that this elegant ornamental technique began to be applied on silverware which clearly imitated the glass bowls, as show by the adoption of the Isings 96 hemispherical bowl form that was lacking from among silver vessels. ${ }^{9}$ The peak in the production of these vessels fell into the later second and early third century, after which their production ceased in the Pontic, Syria and Pannonia, although their manufacture continued up to the fourth century in the west, alongside the creation of increasingly more sophisticated and elaborate geometric patterns. ${ }^{10}$

There remain some gaps in the chronological sequence of how the motifs developed and it is therefore difficult to distinguish between production regions. ${ }^{11}$ In all likelihood, the motif itself was adopted from the ornamentation of clay vessels, although it then had an entirely independent developmental trajectory and ongoing mutual influences between clay and glass vessels decorated in this manner seem unlikely. The appearance of decorative schemes created from facet-cut motifs on silverware without any antecedents can be obviously traced to the popularity of glass vessels. ${ }^{12}$

Rütti highlighted the difficulties in identifying the glass workshops producing these vessels and in determining possible mutual influences between them. Thus, there is no conclusive evidence that the Pannonian glasses had been produced under influence from Syrian wares, ${ }^{13}$ a view shared by Harter, who pointed out that these vessels can hardly be regarded as luxury goods: they were objects of everyday use (tableware) for serving sauces, dressings and side dishes, as suggested by their frequencies in the find assemblages from Mainz and Augst as well as their find contexts. $^{14}$

The facet-cut bowls from Pannonia were first analysed in detail by L. Barkóczi, who distinguished three main groups. ${ }^{15}$ Vessels representing the type principally came to light in Intercisa, Gorsium, Brigetio and Aquincum, but were also attested at Poetovio, Mursa and Sirmium.

\footnotetext{
${ }^{6}$ Paolucci (1997) 63.

${ }^{7}$ Stern (2001) 137.

${ }^{8}$ Stern (2001) 137; Paolucci (1997) 68.

${ }^{9}$ Paolucci (1997) 67, Figs 31-32.
}

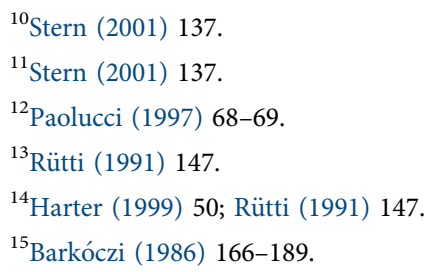




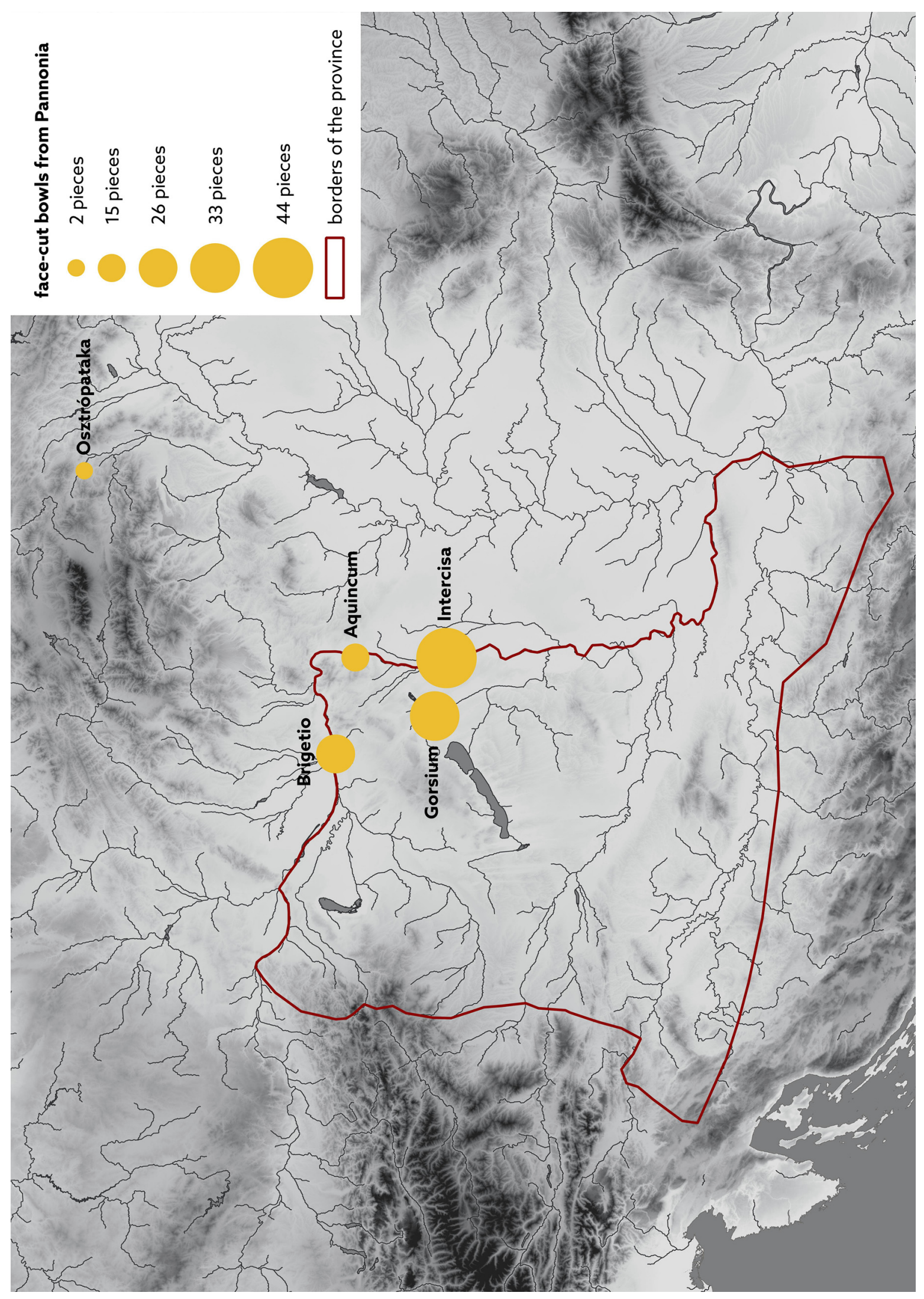

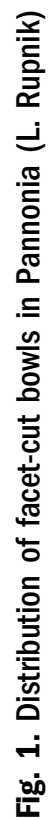


Although facet-cut bowls make their appearance in Pannonia during the second century, the colourless Isings 96 bowls bearing elaborate decorative schemes are distinctive to the earlier third century, to a shorter time period. The facetcut decoration on the colourless, shallower bowls of the late third-early fourth century represents a different type of facet-cut ornamentation, in which cross-hatched lozenges and figural motifs can often be found alongside oval facets. ${ }^{16}$

In Barkóczi's view, the consistent use of certain motifs and their variations as well as their combinations, the uniform quality and colour points towards a local, independent glass industry. He identified impacts from two main regions: from west, along the Rhine-Danube water route, and from Syria. Moreover, given that they are often found in association with chalices with applied ornamentation, they were obviously produced during the same period (earlier third century AD), although Barkóczi assumed that their manufacture was restricted to a briefer, 25-30-year-long period. ${ }^{17}$

Barkóczi distinguished three main groups among the intact and fragmentary bowls known to him based on their decorative motifs. As a matter of fact, only his Groups I and II can be regarded as independent groups since his Group III is essentially made up of the vessels with a unique design that could not be fitted into his other two. ${ }^{18}$ Group I is made up of the earlier vessels dating from later second century, while Group II of vessels with a more elaborate decorative scheme that can be clearly distinguished from the earlier pieces.

Group I: This Group consist of simpler, less complex composition, than Goup II. They are probably dated to the second half of $2^{\text {nd }}$ century.

I.a: A few fragments from Intercisa, Gorsium and Aquincum can be assigned here. Ornamentation: combinations of irregularly and sparsely set round and oval facets. Comparable glass fragments, although with the motifs in a regular arrangement, have been published from the Pontic, Dura Europos and Cologne. ${ }^{19}$

I.b: Bowls with indrawn rim whose entire body is covered with rows of horizontal or vertical oval facets. The size of the rows and the forms of the facets differ. This variety is known from Aquincum, Gorsium and Poetovio. ${ }^{20}$ This ornamental scheme is rarely attested in the Pontic and in the empire's eastern half. $^{21}$

I.c: Hemispherical bowls with cracked-off rim decorated with wheel-cut motifs on the rim or in several bands under the rim. Two rows of oval facets encircle the vessel shoulder, which are in some cases separated by an engraved line from the oval and round facets on the vessel body, whose form

\footnotetext{
${ }^{16}$ Barkóczi (1986) 166; Barkóczi (1988) 64-67.

${ }^{17}$ Barkóczi (1986) 181-182; Barkóczi (1981) 35-70.

${ }^{18}$ Barkóczi (1986) 166.

${ }^{19}$ Sorokina (1978) 111-122; Fremersdorf (1967) Taf. 32, Taf. 37; Clairmont (1963) 307, 309, 313, 325.

${ }^{20}$ Šubic (1974) Taf. VI. 51.

${ }^{21}$ Barkóczi (1986) 167.
}

and size differ from the ones adorning the shoulder, but nevertheless form a uniform decorative system. This type has been reported from Gorsium and Intercisa. The best analogies are the two bowls from Osztrópataka in the Barbaricum. Grave 2, a female burial, yielded two facet-cut glass bowls of this type. ${ }^{22}$

I.d: A row of vertical oval facets under the rim, sometimes combined with a row of horizontal oval facets underneath, followed by rows of round facets down to the vessel base. This variant is known from Aquincum and Intercisa. ${ }^{23}$ Similar bowls can be found both in the west and the east as well as in the Pontic. ${ }^{24}$

I.e: The vessel body is divided into several bands filled with vertical oval and round facets, separated by engraved bundles of lines around the vessel body. This variant has been reported from Intercisa and Gorsium.

Group II: This group comprises the largest number of fragments and represents the most distinctive type in Pannonia.

II.a: The vessel surface is divided into bands separated by wheel-cut lines. The bands are filled with round facets separated by single or double slender bar-shaped motifs, each with an oval facet on top and at the bottom. The centres of the round facets occasionally feature a small decorative blob. ${ }^{25}$ This variant has been found at Gorsium, Intercisa, Aquincum and Brigetio.

II.b: The vessel surface is divided into panels by wheel-cut lines under the rim and around the shoulder. The main motifs in the panels are round facets enclosed within a slender engraved circle, separated by a bar-shaped motif with a horizontal oval facet at both ends. This variant is known from Aquincum and Gorsium.

Group III: Individual pieces that cannot be assigned to either of the above two groups and can be dated to a later period. Oval facets are often combined with cross-hatched lozenges.

The detailed publication of the glass finds, and the identification of stylistic groups is essential to gaining a better understanding of the exact distribution of this attractive and highly decorative ornamental system. The localisation of workshops likewise calls for reports with a focus on the detailed description of the sophisticated

\footnotetext{
${ }^{22}$ Two Vandal royal graves were found at this site, the first in 1790, the second in 1865: the two burials contained a rich array of gold jewellery, bracelets, brooches and silver vessels. The finds are currently housed in the Kunsthistorisches Museum (Vienna) and the Hungarian National Museum (Budapest). The finds from Grave 2 were as follows: a gold neckring of twisted filigree wire, a gold bracelet with flaring terminals, gold finger-rings, brooches, four ornate gold sheets by the feet, a knife, scissors, a belt buckle, an ivory comb, a wooden bucket with silver hoops and mounts, Roman glass cups, a wooden vessel and a Roman gold coin minted in 250 functioning as a funerary obol. The grave dates from the close of the third century: Prohászka (2004).

${ }^{23}$ Barkóczi (1986) 170-171.

${ }^{24}$ Fremersdorf (1967) Taf. 85-86; Sorokina (1978) 114-115.

${ }^{25}$ Barkóczi $(1986,1988)$.
} 
patterns and decorative schemes created from the combination of wheel-cut lines and oval, round and rice-grain facets covering the vessel bodies. The exact description of the patterns themselves and of the thickness of the cuts, an indication of the size of the cutting wheel, is similarly important, as is the description of the design's layout, of whether the facets are loosely or, conversely, closely set, or virtually touching, since this can provide useful clues regarding workshop traditions. For example, a free-blown bowl type covered with shallow, almost touching oval facets, generally dated to the later second-earlier third century, has not other motifs interrupting this monotonous design. This type is not attested in Pannonia, while it is known from Augst. ${ }^{26}$ Designs framed with elongated oval facets are less frequent and can mostly be dated to the second and third centuries. ${ }^{27}$ Decoration made up of large oval facets alternating with cross-hatched motifs is known from Pannonia, although it is less common: these vessels can be assigned to Barkóczi's Group III and fall into the fourth century. ${ }^{28}$ The best-known exemplar representing this type comes from Sopianae: recovered from a burial, the bowl has an early Christian inscription under its rim and is covered with an exceptionally finely executed, elaborate design. ${ }^{29}$ Some of these vessels have very thick walls and the facets are expressly deep, suggesting that at least part of these vessels had been cast rather than blown.

Discussed here will be the hemispherical bowls that fall into Barkóczi's Groups I and II: these are thick-walled, colourless vessels decorated with more elaborate designs combining facet-cut motifs with bar-shaped facets. This decorative technique is wholly perfected on this type, which flourished during a briefer period in Pannonia, for a few decades around the mid-third century. Several pieces, both intact and fragmented, are known principally from Intercisa, Gorsium, Aquincum and Brigetio. These bowls disappear from the Pannonian material as abruptly as they had appeared. One curious coincidence is that the period during which these bowls were used as well as the sites on which they came to light more-or-less coincides with the popularity of the bowls with snake-thread cups, suggesting an association between the two finely decorated glass types. It seems likely that they had been produced in the same workshops and by the same craftsmen, possibly by Syrian glassblowers who were in all likelihood active in Pannonia during this period: we can perhaps assume that both wares can be linked to them.

The same period, the mid-third century, saw the heyday of bowls with elaborate facet-cut decoration in Germany too, as shown by the find material from the Cologne area and Augst, in which it is amply represented. The ornamental repertoire combining oval and round facets with bar-shaped

\footnotetext{
${ }^{26}$ Isings (1957) Form 116; Rütti (1991) Form AR 58; Fünfschilling (2015) 88.

${ }^{27}$ Fünfschilling (2015) 88.

${ }^{28}$ Fünfschilling (2015) 88; Barkóczi (1988) Kat. 45, Kat 165.

${ }^{29}$ Fülep (1975) 35-36; Fülep (1977) 36, Taf. 25, Grave 192.
}

facets framing and separating them on the vessel body divided into bands was indeed endless. ${ }^{30}$ The pieces from Augusta Raurica can be assigned to the later third century, while the twelve vessels with a comparable decoration from Colchester have been dated to the $230 \mathrm{~s} .{ }^{31}$ The exemplars from Swiss sites date from the third century. ${ }^{32}$

Similar vessels have been published from Dura Europos. The city's occupation by the Sasanians in 256/257 can be regarded as a terminus ante quem for this bowl type, the implication being that hemispherical bowls adorned with these elegant designs were known before this date, ${ }^{33}$ an important chronological anchor, even if the designs differ from the ones known from Pannonia. The fragments from Ostia date from around the 240s. ${ }^{34}$ Vessels with facet-cut ornamentation were produced in several smaller specialised workshops: one task ahead of us is the mapping of the styles and motif combinations typical for one or another workshop.

Examining the spatial distribution within Pannonia (Fig. 1), the following can be established: 15 from Aquincum, 44 from Intercisa, 33 from Gorsium, 2 from Ostrópataka, 4 from Brigetio, and 8 from pieces of unknown location. This is joined by another 22 fragments from the Brigetio in the current publication.

In the following, I shall present the bowls from Pannonia, specifically the pieces found at Brigetio, ornamented with this attractive decorative scheme of round and oval facets separated by bar-shaped facets arranged into wheelcut bands.

Fourteen glass fragments (From Intercisa and Brigetio) were submitted to archaeometric analyses to determine whether the particularly good quality, thick-walled, colourless vessels had a specific composition and whether there were any differences in their composition. We were also curious to learn whether these complex ornamental schemes with deep-cut facets called for a special composition and whether the raw glass used for these bowls came from one specific location. The results will be published in a subsequent study.

The primary purpose of this article is to summarize the information we already know about the decoration system of Isings 96 facetted bowls following the work of L. Barkóczi. To move on, in order to be able to identify workshop circles, the first step is to communicate in detail the individual bowls and fragments, with good quality photographs and drawings.

The following is a catalogue of the fragments found at the Brigetio. Only a few fragments had been published before, for the most part they contain unpublished fragments known from recent excavations. Respectively, they were previously published only in excavation reports. ${ }^{35}$

\footnotetext{
${ }^{30}$ Fünfschilling (2015) 88.

${ }^{31}$ Cool and Price (1995) 78.

${ }^{32}$ Fünfschilling (2015) 89.

${ }^{33}$ Clairmont (1963) 266-269, Taf. XXVI.

${ }^{34}$ Carandini (1968) 23.

${ }^{35}$ Bartus et al. (2015) 13-16; Bartus et al. (2016) 116-117; Bartus et al. (2014) 45-48.
} 
There are 2 bowls in the collection of the Hungarian National Museum (Fig. 4.3 and Fig. 5.2-3), 21 fragments in the collection of the György Klapka Museum (Fig. 2, Fig. 3, Fig. 6), Komárom from the excavations of recent years and only 2 fragments from the Kuny Domokos Museum, Tata (Fig. 4.1-2). Barkóczi L. mentioned one impact bowl from Brigetio from the Kunsthistorisches Museum, Wien (Fig. 4.4). ${ }^{36}$

A new arrangement of decorative elements appears based on new fragments of Brigetio. In the following sequential articles, I would like to publish in detail all fragments known from Intercisa and Gorsium, as well as Aquincum, and to create a new typological grouping. With the publication of the new fragments, a wide variety of patterns appear in Brigetio. 1: Zoned decoration with round facets separated by single or double slender bar-shaped motifs, each with an oval facet on top and at the bottom. 2: Zoned decoration with rows of horizontal and vertical facets, or rows of simple circular facets. 3: Round facets enclosed within a slender engraved circle, separated by a bar-shaped motif with a horizontal oval facet at both ends (Fig. 6).

Based on the fragments previously reported, Intercisa and Gorsium dominated, as most fragments are known from. With the new specimens just published, the picture is much more nuanced, as we also know 26 fragments from the Brigetio, a number that approximates the quantitative data of the first two sites (Fig. 1).

\section{CATALOGUE}

1. Brigetio/Kunsthistorisches Museum, Wien. Inv. no.:-. Hemishpherical deep convex bowl, colourless; decoration: zoned decoration $\mathrm{H}: 7.2 \mathrm{~cm}$, Dm: $11.8 \mathrm{~cm}$, Base: $2 \mathrm{~cm}$. Barkóczi 1988, 65, Kat. Nr. 40, Taf. LXXI.

Date: $3^{\text {rd }}$ century (Fig. 4.4)

2. Brigetio/Szöny-Vásártér, Klapka György Museum. Inv. no.: 2002.H13.38.9. Fragment of a hemispherical deep convex bowl with facet-cut, colourless; decoration: zoned decoration with circular ovals the circles are separated by doble vertical engraved lines enclosing at the top with narrow ovals. Horizontal wheel-cut line below and a row of vertically standing narrow facets. Thick: $36 \mathrm{~mm}$. (Fig. 2.1, Fig. 6.2)

Date: $3^{\text {rd }}$ century

3. Brigetio/Szöny-Vásártér, Klapka György Museum. Inv. no.: 2002.H13.38.18. Fragment of a hemispherical deep convex bowl with facet-cut, colourless; decoration: zoned decoration with circular oval and separated by doble vertical engraved lines. Double horizontal wheelcut line below. Thick: $23 \mathrm{~mm}$. (Fig. 2.2)

Date: $3^{\text {rd }}$ century

4. Brigetio/Szőny-Vásártér, Klapka György Museum. Inv. no.: 2002.G12.86.6. Fragment of a hemispherical deep convex bowl with facet-cut, colourless; decoration: zoned decoration with separating vertical engraved lines

${ }^{36}$ Barkóczi (1988) Kat. 40. enclosing at the top with narrow ovals. Horizontal wheel-cut line below. Thick: $23 \mathrm{~mm}$. (Fig. 2.3)

Date: $3^{\text {rd }}$ century

5. Brigetio/Szőny-Vásártér, Klapka György Museum. Inv. no.: 1994.-B13.46.11. Fragment of a hemispherical deep convex bowl with facet-cut, colourless; decoration: zoned decoration with circular oval and with fragment of separating vertical engraved lines fragment. Thick: $15 \mathrm{~mm}$. (Fig. 2.4)

Date: $3^{\text {rd }}$ century

6. Brigetio/Szőny-Vásártér, Klapka György Museum. Inv. no.: 1995.F13.57.791. Fragment of a hemispherical deep convex bowl with facet-cut, colourless; decoration: zoned decoration: three zones, the zones are separated by horizontal wheel-cut lines. The three zones are the same: circular ovals have central bosses; the circles are separated by simple vertical engraved lines enclosing at the top with narrow ovals. Thick: $34 \mathrm{~mm}$. (Fig. 2.5, Fig. 6.2)

Date: $3^{\text {rd }}$ century

7. Brigetio/Szőny-Vásártér, Klapka György Museum. Inv. no.: 2001.G13.10.7. Fragment of a hemispherical deep convex bowl with facet-cut, colourless; decoration: zoned decoration with fragment of two circular ovals have a central bosses and separated by simple vertical engraved lines enclosing at the top with narrow ovals. Thick: $15 \mathrm{~mm}$. (Fig. 2.6)

Date: $3^{\text {rd }}$ century

8. Brigetio/Szőny-Vásártér, Klapka György Museum. Inv. no.: 2003.H13.79.54. Fragment of a hemispherical deep convex bowl with facet-cut, colourless; decoration: zoned decoration with fragment of circular oval have a central boss and separated by double vertical engraved lines enclosing at the top with narrow ovals. Thick: $32 \mathrm{~mm}$. (Fig. 2.7)

Date: $3^{\text {rd }}$ century

9. Brigetio/Szőny-Vásártér, Klapka György Museum. Inv. no.: 2001.G13.10.24. Fragment of a hemispherical deep convex bowl with facet-cut, colourless; decoration: zoned decoration with fragment of circular oval and separated by simple vertical engraved lines enclosing at the top with narrow ovals. Thick: $12 \mathrm{~mm}$. (Fig. 2.8) Date: $3^{\text {rd }}$ century

10. Brigetio/Szőny-Vásártér, Klapka György Museum. Inv. no.: 1993.E11.120.80. Base fragment of a hemispherical deep convex bowl with facet-cut, colourless; decoration: zoned decoration double horizontal wheel cut lines and a row of vertical narrow ovals below. Thick: $20 \mathrm{~mm}$. (Fig. 2.9)

Date: $3^{\text {rd }}$ century

11. Brigetio/Szőny-Vásártér, Klapka György Museum. Inv. no.: 2001.G13.18.39. Fragment of a hemispherical deep convex bowl with facet-cut, colourless; decoration: zoned decoration with fragment of circular oval have central bosses. Horizontal wheel-cut line below. Thick: $16 \mathrm{~mm}$. (Fig. 2.10) Date: $3^{\text {rd }}$ century

12. Brigetio/Szőny-Vásártér, Klapka György Museum. Inv. no.: 2001.G13.18.40. Fragment of a hemispherical 
deep convex bowl with facet-cut, colourless; decoration: zoned decoration with fragment of simple vertical engraved lines enclosing at the top with narrow ovals. Horizontal wheel-cut line below. Thick: $10 \mathrm{~mm}$. (Fig. 2.11) Date: $3^{\text {rd }}$ century

13. Brigetio/Szőny-Vásártér, Klapka György Museum. Inv. no.: 2001.G13.18.41. Fragment of a hemispherical deep convex bowl with facet-cut, colourless; decoration: zoned decoration with fragment of circular oval have central bosses and separated by simple vertical engraved lines enclosing at the top with narrow ovals. Horizontal wheel-cut line below. Thick: $10 \mathrm{~mm}$. (Fig. 2.12)

Date: $3^{\text {rd }}$ century

14. Brigetio/Szőny-Vásártér, Klapka György Museum. Inv. no.: 2001.G13.18.41. Fragment of a hemispherical deep convex bowl with facet-cut, colourless; decoration: zoned decoration with fragment of circular oval Thick: $16 \mathrm{~mm}$. (Fig. 2.13)

Date: $3^{\text {rd }}$ century

15. Brigetio/Szőny-Vásártér, Klapka György Museum. Inv. no.: 1993.E11.120.80. Base fragment of a hemispherical deep convex bowl with facet-cut, colourless; decoration: zoned decoration horizontal wheel cut lines and a row of vertical narrow ovals below. Thick: $22 \mathrm{~mm}$. (Fig. 2.14)

Date: $3^{\text {rd }}$ century

16. Brigetio/Szőny-Vásártér, Klapka György Museum. Inv. no.: 2012.M15-16.043.17-19. Fragment of a hemispherical deep convex bowl with facet-cut, colourless; decoration: zoned decoration horizontal wheel cut lines and circular ovals in two horizontal rows. Thick: $21 \mathrm{~mm}$. (Fig. 3.1)

Date: $3^{\text {rd }}$ century

17. Brigetio/Szőny-Vásártér, Klapka György Museum. Inv. no.: 2012.M13-14.009.64-65. Fragment of a hemispherical deep convex bowl with facet-cut, colourless; decoration: zoned decoration longed narrow ovals in two horizontal rows just below the rim and circular ovals have central bosses separated by simple vertical engraved lines enclosing at the top with narrow ovals belows. Thick: $22 \mathrm{~mm}$. (Fig. 3.2)

Date: $3^{\text {rd }}$ century

18. Brigetio/Szőny-Vásártér, Klapka György Museum. Inv. no.: 2013.L17-M17.057.17. Fragment of a hemispherical deep convex bowl with facet-cut, colourless; decoration: zoned decoration circular ovals have central bosses separated by simple vertical engraved lines enclosing at the top with narrow ovals, horizontal wheel cut lines and circular ovals have central bosses below. Thick: $31 \mathrm{~mm}$. (Fig. 3.3)

Date: $3^{\text {rd }}$ century

19. Brigetio/Szőny-Vásártér, Klapka György Museum. Inv. no.: 2013.N15.032.27. Fragment of a hemispherical deep convex bowl with facet-cut, colourless; decoration: zoned decoration: two zones, double separating vertical engraved lines enclosing at the top with narrow ovals, horizontal wheel cut lines and simple vertical engraved lines and circular oval fragment. Thick: 25 mm. (Fig. 3.4,
Fig. 6.4.)

Date: $3^{\text {rd }}$ century

20. Brigetio/Szőny-Vásártér, Klapka György Museum. Inv. no.: 2013.L17-M17.057.12,14. Rimfragment of a hemispherical deep convex bowl with facet-cut, colourless; decoration: zoned decoration: Below the rim are two rows of thin, vertical faceted ovals, below it a horizontally running wheel-cut banded, and another field of larger faceted ovals. Dm: 99 mm, Thick: 25 mm. (Fig. 3.5, Fig. 6.6.)

Date: $3^{\text {rd }}$ century

21. Brigetio/Szőny-Vásártér, Klapka György Museum. Inv. no.: 2014.P018-P019.204. Fragment of a hemispherical deep convex bowl with facet-cut, colourless; decoration: zoned decoration: circular ovals have central bosses, horizontal wheel cut lines and circular oval by simple separating vertical engraved lines enclosing at the top with narrow ovals surrounded on two sides. Thick: $31 \mathrm{~mm}$. (Fig. 3.6, Fig. 6.5.)

Date: $3^{\text {rd }}$ century

22. Brigetio/Szőny-Vásártér, Klapka György Museum. Inv. no.: 2014.O18-O19.075.83. Fragment of a hemispherical deep convex bowl with facet-cut, colourless; decoration: zoned decoration: a bundle of thick, horizontal wheel-cut lines, a row of narrow, vertical ovals and other horizontal wheel-cut lines below. Thick: $16 \mathrm{~mm}$. (Fig. 3.7, Fig. 6.3.)

Date: $3^{\text {rd }}$ century

23. Brigetio/Hungarian National Museum. Inv. no.: 4.1933.82. Basefragment of a hemispherical deep convex bowl with facet-cut, colourless; decoration: zoned decoration: vertical, narrow engraved double lines in a row, horizontal wheel-cut lines below and circular ovals separated by curved lines enclosing at the top with narrow ovals. Thick: $24 \mathrm{~mm}$. (Fig. 4.3, Fig. 5.2)

Date: $3^{\text {rd }}$ century

24. Brigetio/Hungarian National Museum. Inv. no.: 29.1929.2. Hemispherical deep convex bowl with facetcut, out-turned rim, edge cracked-off, colourless; decoration: two horizontal wheel-cut lines under the rim and five rows circular facets. $\mathrm{H}: 6.8 \mathrm{~cm}$, Dm: $7.6 \mathrm{~cm}$, Base: $1.5 \mathrm{~cm}$, Thick: $24 \mathrm{~mm}$. (Fig. 5.3)

Date: $3^{\text {rd }}$ century

25. Brigetio/Kuny Domokos Museum. Inv. no.: 72.71.4. Fragment of hemispherical deep convex bowl with facet-cut, colourless; decoration: narrow vertical ovals in a row, two horizontal wheel-cut lines and circular ovals in a row, larger ovals separated by simple vertical engraved lines enclosing at the top with narrow ovals. Thick: $26 \mathrm{~mm}$. (Fig. 4.2)

Date: $3^{\text {rd }}$ century

26. Brigetio/Kuny Domokos Museum. Inv. no.: 55.2.244. Fragment of hemispherical deep convex bowl with facet-cut, colourless; decoration: circular ovals separated by narrow ovals, horizontal narrow ovals below and followed by two rows of vertical narrow ovals. Thick: $22 \mathrm{~mm}$. (Fig. 4.1)

Date: $3^{\text {rd }}$ century 


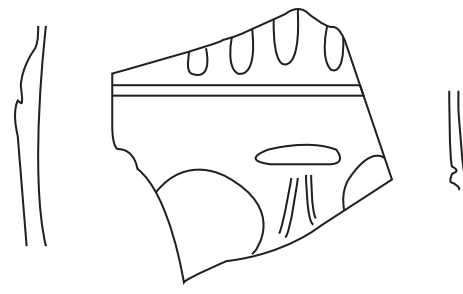

1.

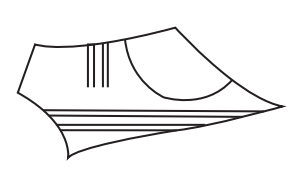

2.

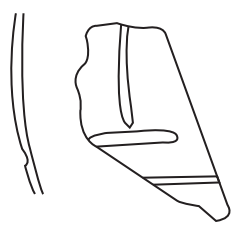

3.

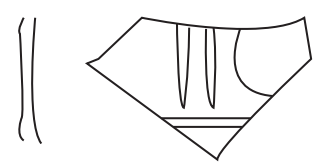

4.
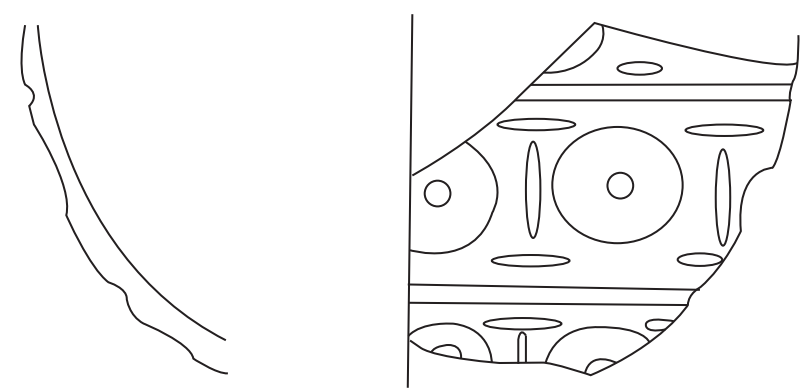

5.

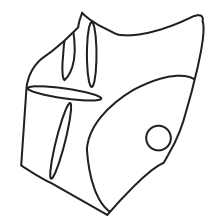

7.

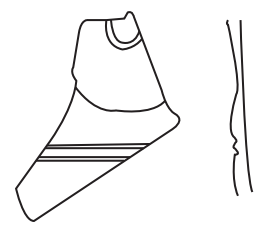

10
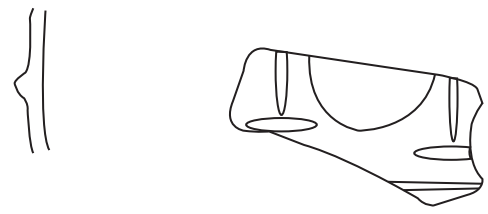

8.

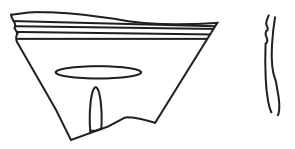

11.

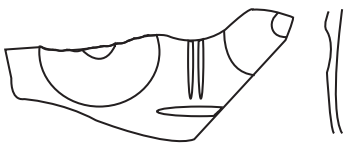

6.

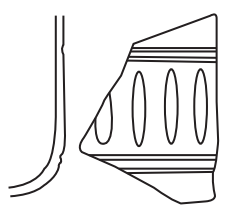

9.

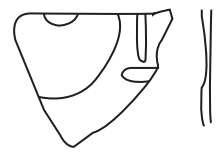

12.
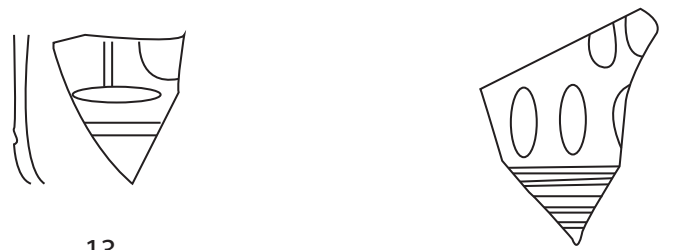

14.

13.
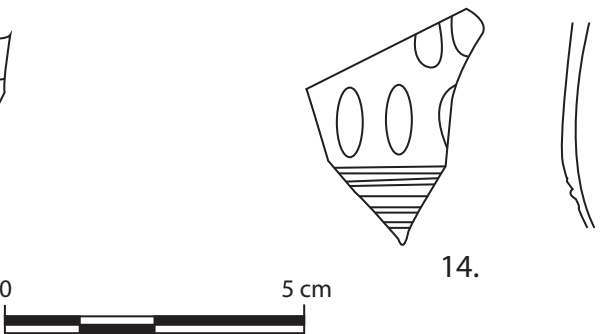

Fig. 2. Fragments of facet-cut bowls from Brigetio. 1: Cat. 2; 2: Cat. 3; 3: Cat. 4; 4: Cat. 5; 5: Cat. 6; 6: Cat. 7; 7: Cat. 8; 8: Cat. 9; 9: Cat. 10; 10: Cat. 11; 11: Cat. 12; 12: Cat. 13; 13: Cat. 14; 14: Cat. 15 

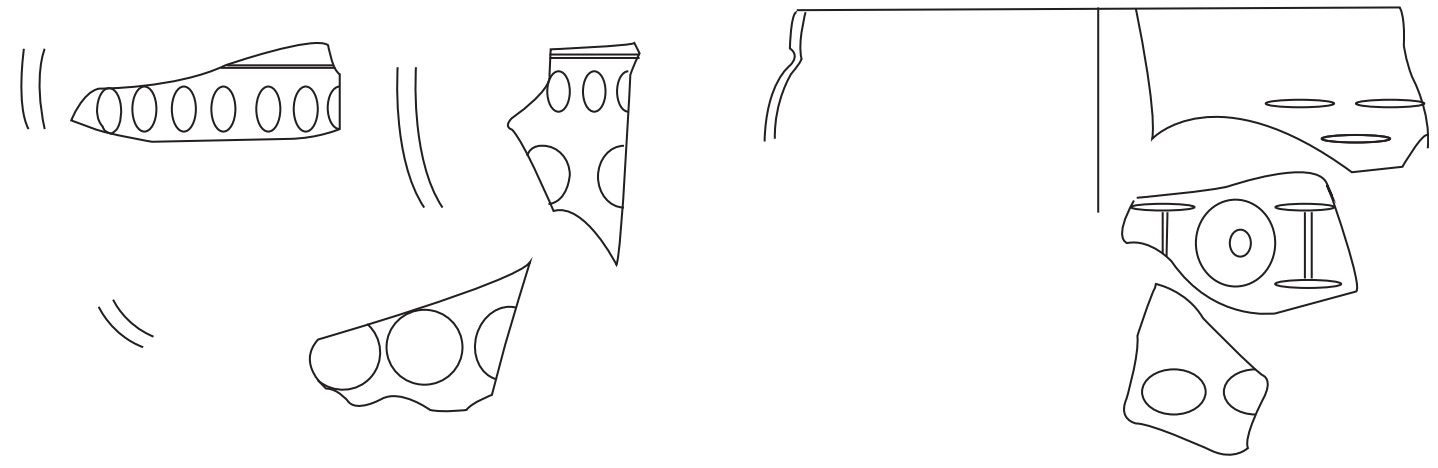

1.

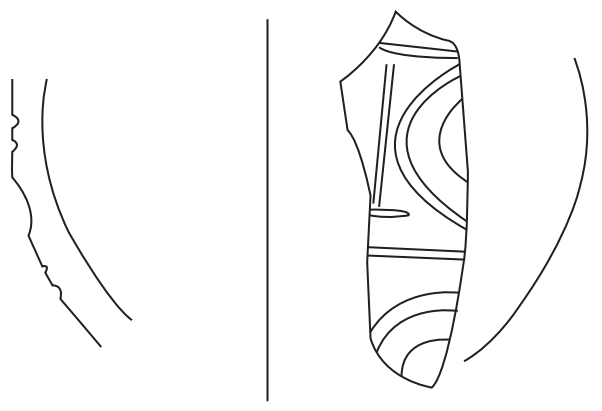

2.

3.

4.

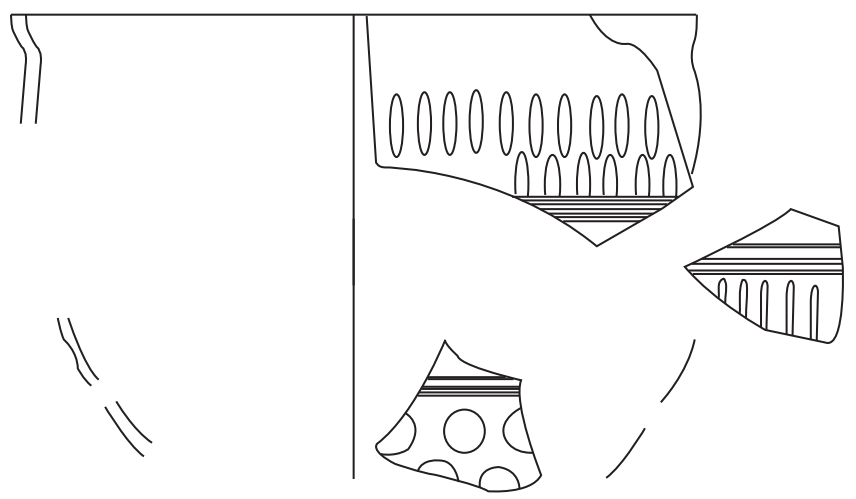

5.
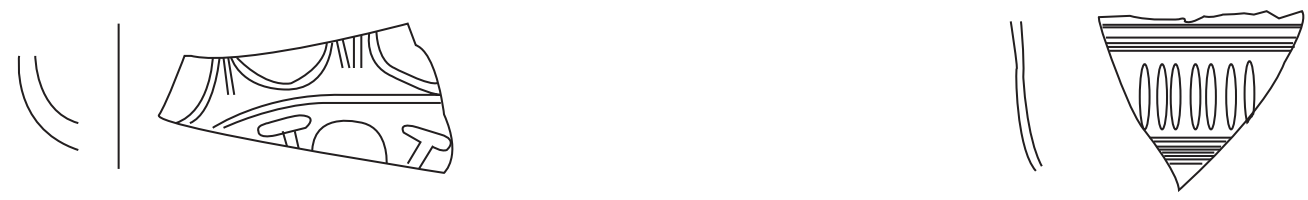

6.

7.

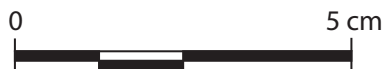

Fig. 3. Fragments of facet-cut bowls from Brigetio. 1: Cat. 16; 2: Cat. 17; 3: Cat. 18; 4: Cat. 19; 5: Cat. 20; 6: Cat. 21; 7: Cat. 22 


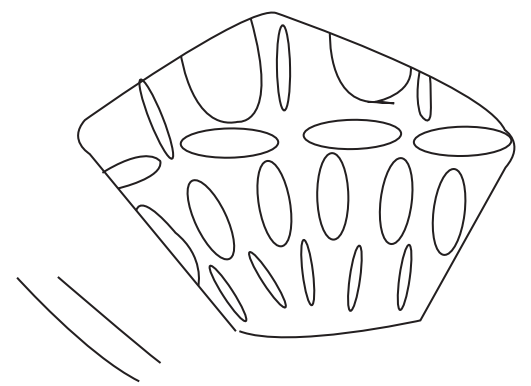

1.
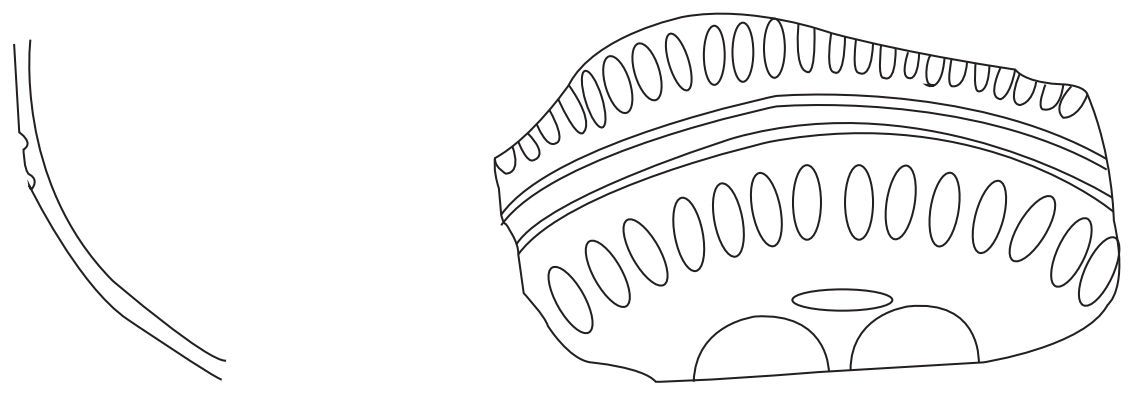

2.
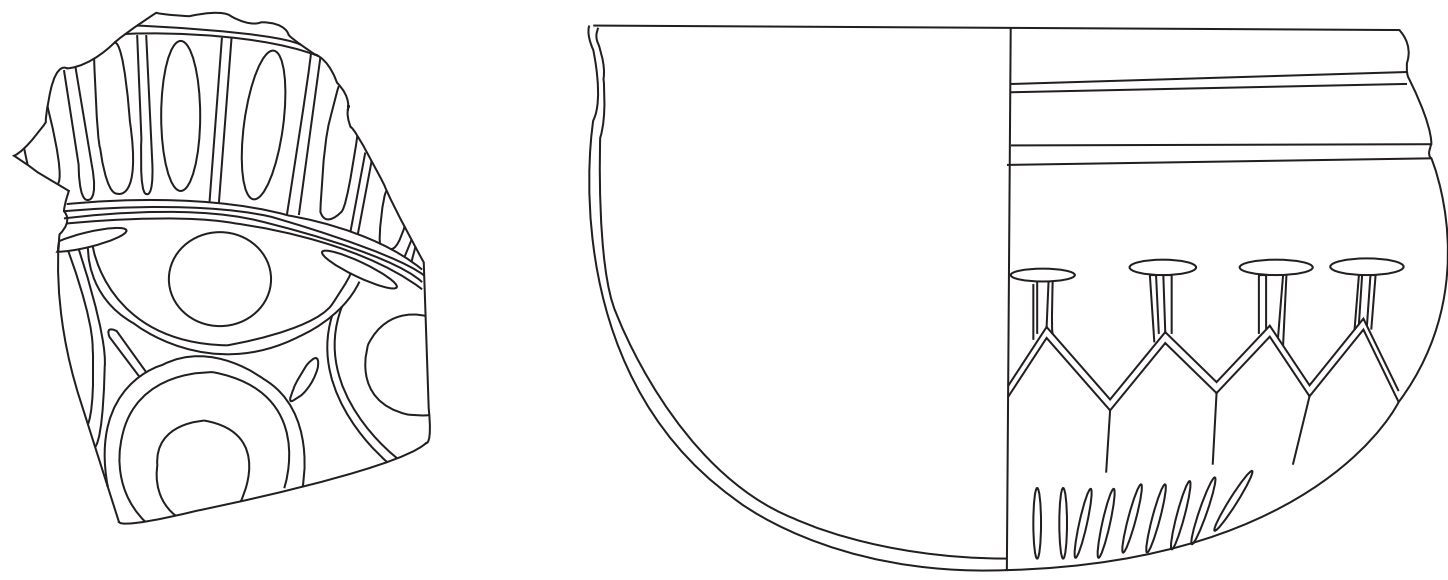

3.

4.

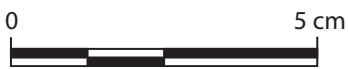

Fig. 4. Fragments of facet-cut bowls from Brigetio. 1: Cat. 26; 2: Cat. 25; 3: Cat. 23; 4: Cat. 1 


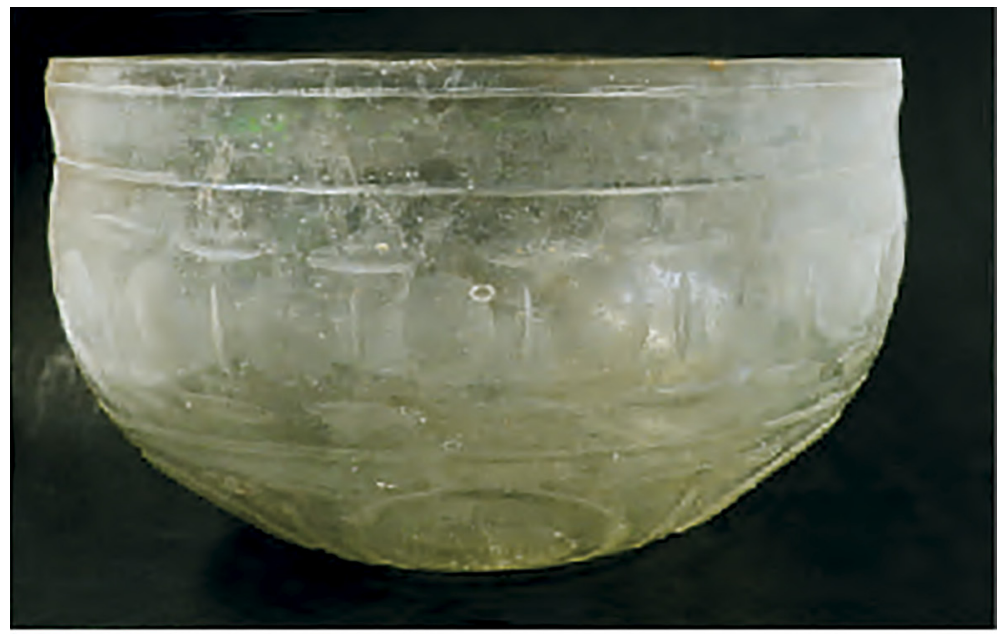

1.

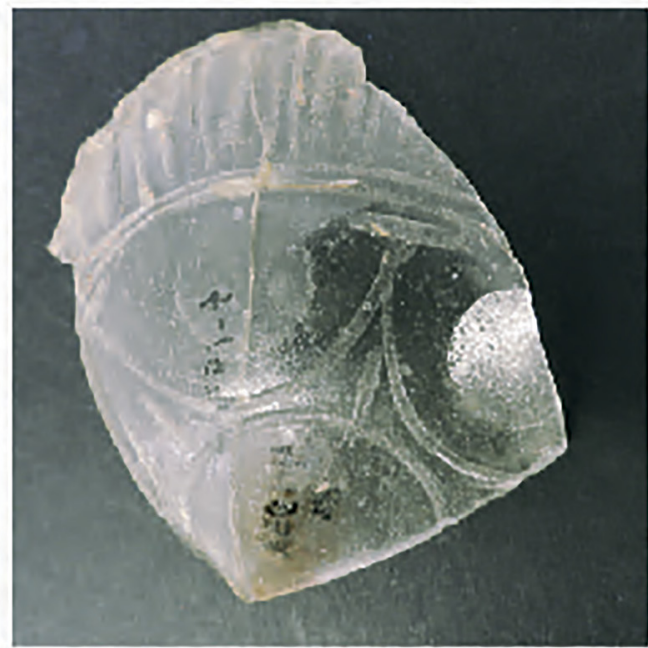

2.

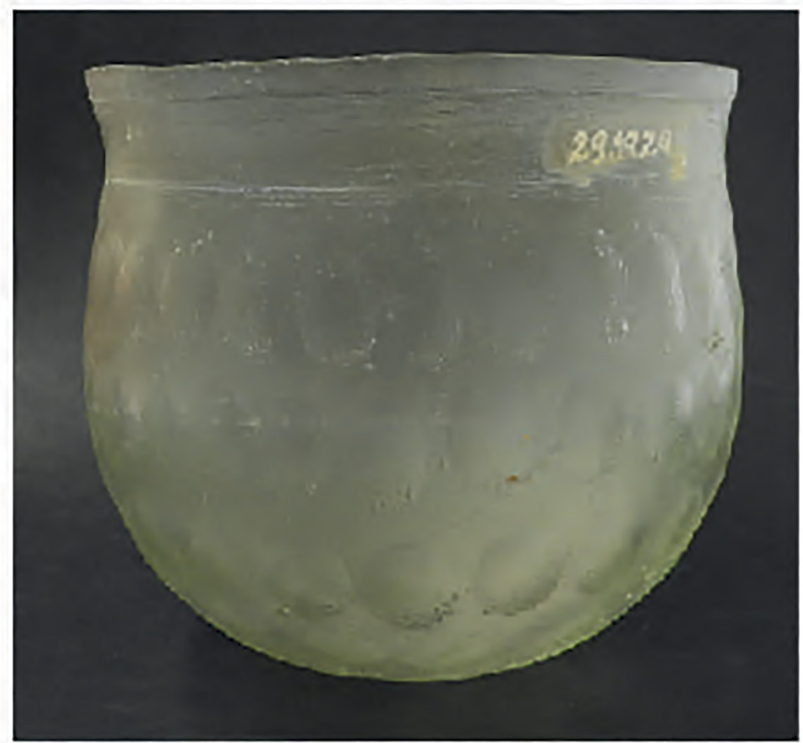

3.

Fig. 5. Facet-cut bowls from Pannonia. 1: Facet-cut bowl from Pannonia. Inv. no.: 1.1921. Hungarian National Museum. Unknown findplace (Photo: K. Dévai); 2-3: Facet-cut bowls from Brigetio. Inv. no.: 4.1933.82. and 29.1929.2. Hungarian National Museum. $2=$ Cat. 23 (photo: K. Dévai), $3=$ Cat. 24 (Photo: K. Dévai) 


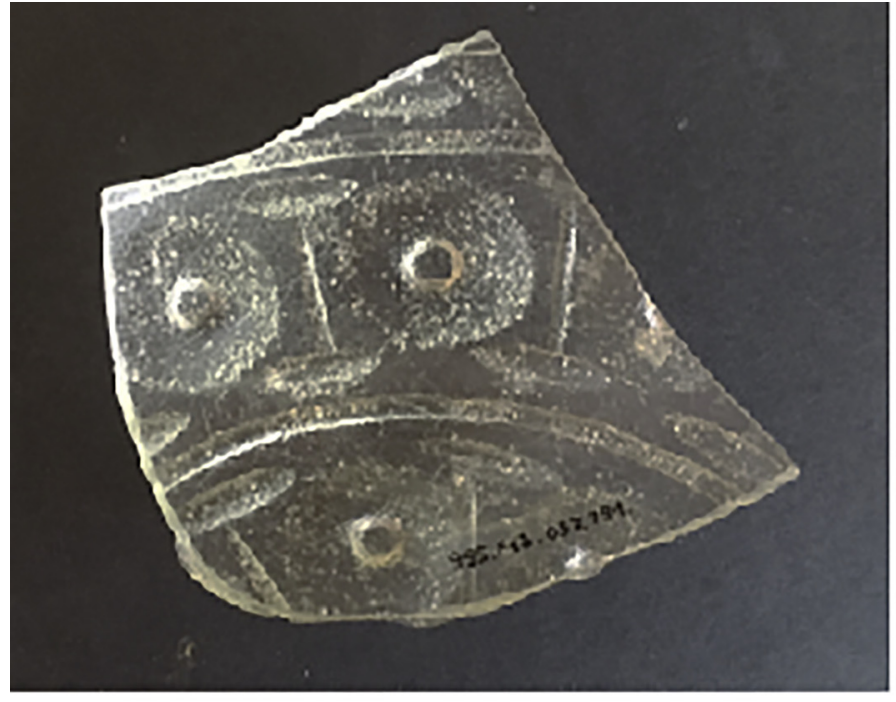

1.

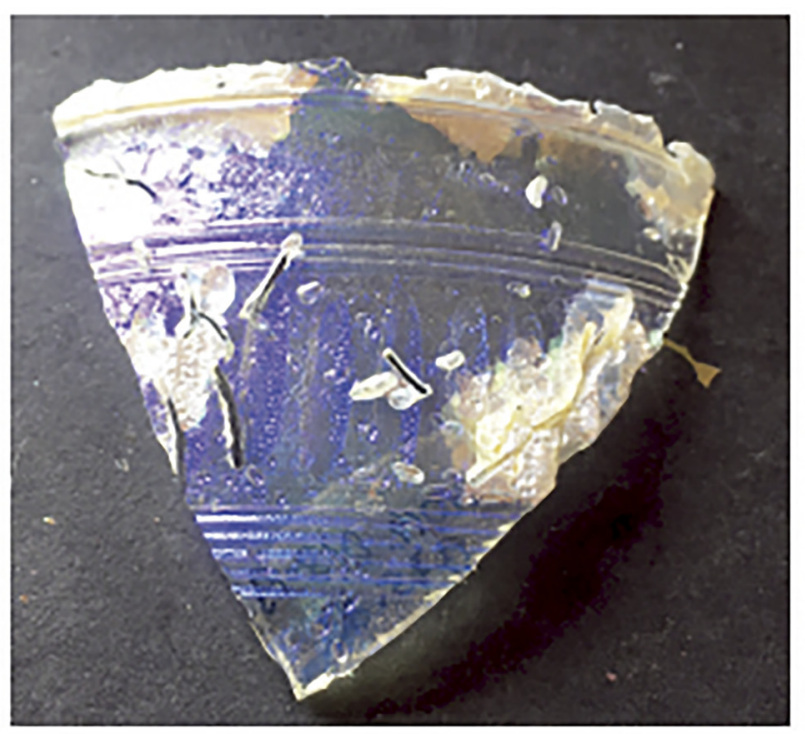

3.

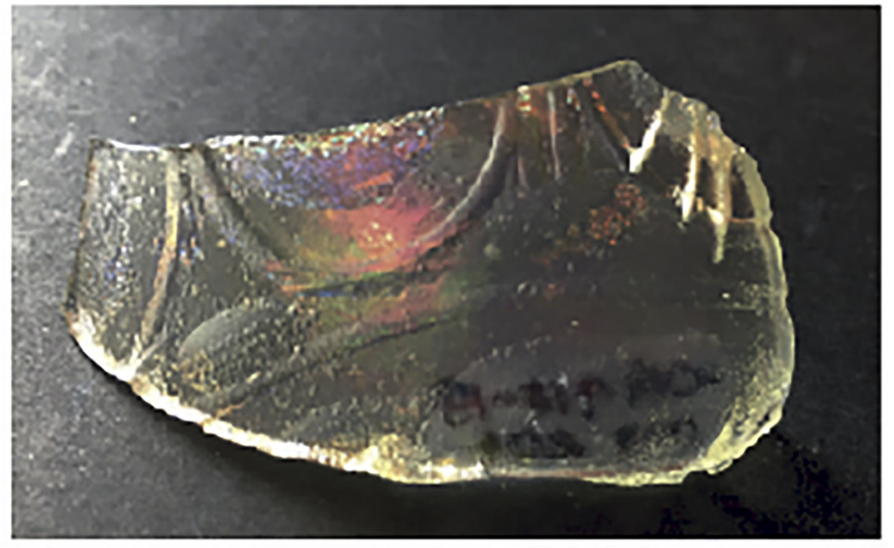

5.

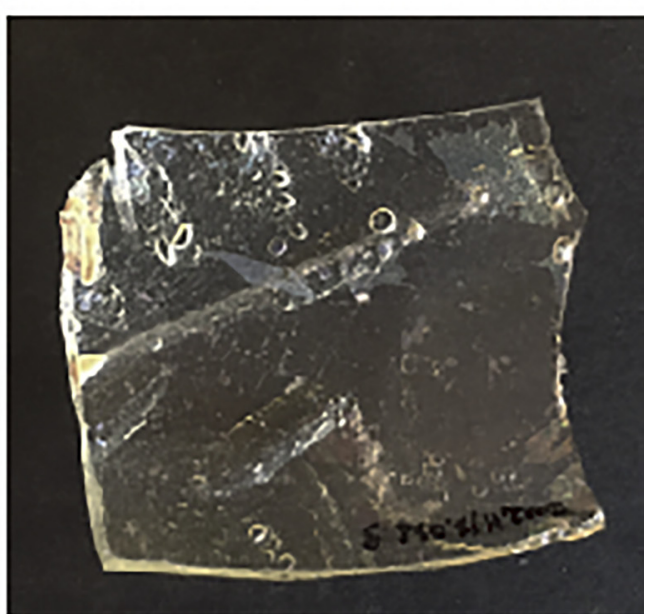

2.

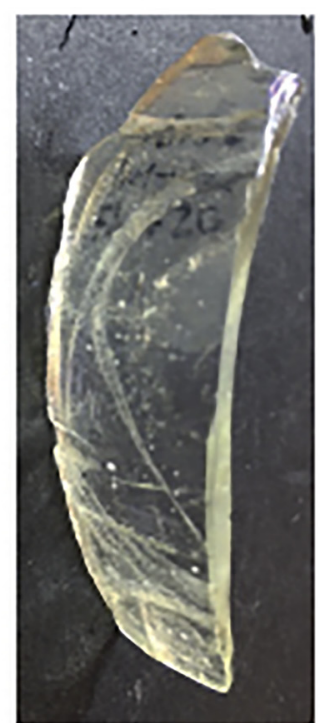

4.

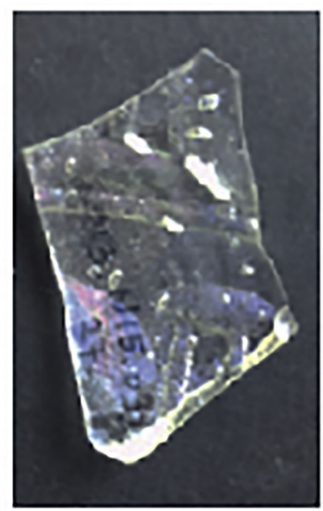

6.

Fig. 6. Fragments of facet-cut bowls from Brigetio (Photo: K. Dévai). 1: Cat. 6; 2: Cat. 2; 3: Cat. 22; 4: Cat. 19; 5: Cat. 21; 6: Cat. 20 


\section{REFERENCES}

Barkóczi, L. (1981). Kelche aus Pannonien mit Fadenauflage und Gravierung. ActaArchHung, 33: 35-70.

Barkóczi, L. (1986). A 3. sz. első feléből származó vésett díszü üvegek Pannoniában (Geschliffene Gläser aus der ersten Hälfte des 3. Jhs in Pannonien). ArchÉrt, 113: 166-189.

Barkóczi, L. (1988). Pannonische Glasfunde in Ungarn. StudArch 9. Budapest.

Bartus, D., Borhy, L., Delbó, G., Dévai, K., Kis, Z., Hajdu, B., Nagy, A., Sáró, Cs., Sey, N., Számadó, E., and Juhász, L. (2016). Jelentés a Komárom-Szőny, Vásártéren 2014-ben folytatott régészeti feltárások eredményeiről (Bericht über die Ergebnisse der in Brigetio (FO: Komárom-Szőny, Vásártér) im Jahre 2014 geführten archäologischen Ausgrabungen). KEMMK, 22: 113-168.

Bartus, D., Borhy, L., Delbó, G., Dévai, K., Kis, Z., Nagy, A., Sáró, Cs., Sey, N., Számadó, E., and Vida, I. (2015). Jelentés a KomáromSzőny, Vásártéren 2013-ben folytatott régészeti feltárások eredményeiről (Bericht über die Ergebnisse der in Brigetio (FO: Komárom-Szőny, Vásártér) im Jahre 2013 geführten archäologischen Ausgrabungen). KEMMK, 21: 7-51.

Bartus, D, Borhy, L., Delbó, G., Dévai, K., Kis, Z., Nagy, A., Sey, N., Számadó, E., Szórádi, Zs., and Vida, I. (2014). Jelentés a Komárom-Szőny, Vásártéren 2012-ben folytatott régészeti feltárások eredményeiről (Bericht über die Ergebnisse der in Brigetio (FO: Komárom-Szőny, Vásártér) im Jahre 2012 geführten archäologischen Ausgrabungen). KEMMK, 20: 33-90.

Carandini, A. (1968). Ostia: Le Terme del Nuotatore: Scavo dell'ambiente IV/1. Roma.

Clairmont, C.W. (1963). The excavations at Dura-Europos, conducted by Yale University and the French Academy of Inscriptions and Letters, Final Report IV. 5.: The glass vessels. New Haven.

Cool, H.M.E., and Price, J. (1995). Roman vessel glass from excavations in Colchester, 1971-1985. ColchArchRep 8. Colchester.
Cottam, S., and Price, J. (1998). Romano-British glass vessels: A handbook. York.

Fremersdorf, F. (1967). Die römischen Gläser Schliff, Bemalung und Goldauflagen aus Köln. Köln.

Fülep, F. (1975). Sopianae: A római kori Pécs (Roman Pécs). Pécs.

Fülep, F. (1977). Roman cemeteries on the territory of Pécs (Sopianae). FontArchHung. Budapest.

Fünfschilling, S. (2015). Die römischen Gläser aus Augst und Kaiseraugst: kommentierter Formenkatalog und ausgewählte Neufunde 1981-2010 aus Augusta Raurica. FiA 51. Augst.

Harter, G. (1999). Römishe Gläser des Landesmuseums Mainz. Wiesbaden.

Hoffmann, B. (2002). Römisches Glas aus Baden-Württemberg. Stuttgart.

Isings, C. (1957). Roman glass. Groeningen-Djakarta.

Paolucci, F. (1997). I vetri inicisi dall'Italia settentrionale e dalla Rezia. Nel periodo medio e trado imperiale. Firenze.

Prohászka, P. (2004). Az osztrópatakai vandál királysír (Das vandalische Königsgrab von Osztrópataka/Ostrovany, SK/). Esztergom.

Rütti, B. (1991). Die römischen Gläser aus Augst und Kaiseraugst. FiA 13. Augst.

Sakl-Oberthaler, S., and Tarcsay, K. (2001). Römische Glasformen aus Wien. Fundort Wien. Berichte zur Archäologie, 4: 78-112.

Šaranović-Svetek, V. (1986). Antičko staklo u Jugoslovenskom delu provincije donje Panonije [Ancient glass in the Yugoslavian part of the province of Lower Pannonia]. Novi Sad.

Sorokina, N. (1978). Facettenschliffgläser des 2en-3en Jhd. u. z. aus dem Schwarzmeergebiet. AIHV, 7: 111-122.

Stern, E.M. (2001). Römisches, byzantinisches und frühmittelalterliches Glas. 10 v. Chr.-700 n. Chr. Sammlung Ernesto Wolf. Ostfildern.

Šubic, Z. (1974). Tipološki in kronološki pregled rimskega stekla v Poetovioni - Revue typologique et chronologique de verre romain de Poetovio. AV, 25: 39-61. 